\title{
Pengaruh Macam Inokulum dan Lama Inkubasi Pupuk Organik Terhadap Pertumbuhan dan Hasil Padi
}

\author{
DOI 10.18196/pt.2014.021.36-43
}

\section{Sarjiyah}

Program Studi Agroteknologi, Fakultas Pertanian, Universitas Muhammadiyah Yogyakarta,Jl. Lingkar Selatan, Kasihan, Bantul, Yogyakarta 55183; e-mail:sarjiyahsml@yahoo.com

\begin{abstract}
ABSTRAK
Penelitian ini bertujuan untuk mengetahui macam inokulan dan lama inkubasi dalam pembuatan pupuk organik yang dapat memberikan pengaruh paling baik pada pertumbuhan dan hasil padi. Penelitian dilakukan di Kasihan, Bantul, Yogyakarta pada ketinggian tempat $110 \mathrm{~m}$ dpl dengan jenis tanah regosol.Penelitian dilaksanakan dengan metode percobaan lapangan dengan rancangan perlakuan faktorial 3 × 4, ditambah 1 perlakuan kontrol yang disusun dalam Rancangan Acak Kelompok Lengkap dengan 3 blok sebagai ulangan. Faktor yang diujjkan adalah macam inokulan yang ditambahkan dalam pembuatan pupuk organik, terdiri atas 3 aras yaitu tanpa inokulan, EM4 dan Stardec, sedangkan faktor lama inkubasi pupuk organik terdiri dari 4 aras yaitu 7 hari, 14 hari, 21 hari dan 28 hari ditambah 1 perlakuan kontrol dengan menggunakan pupuk anorganik (Urea, SP36 dan KCl) sesuai dosis anjuran, sehingga ada 13 perlakuan.Hasil penelitian menunjukkan bahwa pupuk organik tanpa inokulan, penggunaan inokulan EM4 maupun Stardec dalam pembuatan pupuk organik (pupuk kandang ayam) dengan lama inokulasi 1-4 minggu tidak berpengaruh nyata terhadap pertumbuhan dan hasil padi Varietas Mentik Wangi. Penggunaan pupuk organik (pupuk kandang ayam) 3 ton/hektar tanpa inokulan, dengan menggunakan inokulan EM4 maupun Stardec memberikan hasil padi yang tidak berbeda nyata dengan hasil padi menggunakan pupuk anorganik.

Kata Kunci: Padi, Oryza sativa L, Inokulum, Pupuk Organik
\end{abstract}

\section{ABSTRACT}

The experiment aimed to know the best inoculant and incubation time of organic fertilizer to the growth and yield of paddy. The experiment was conducted in Kasihan, Bantul, Yogyakarta. The altitude of experiment site is $110 \mathrm{~m}$ above sea level with the soil type of regosol. The experiment used the $3 \times 4$ factorial with one control and was arranged in Randomized Completely Block Design with three block as replication. The first factor was kind of inoculant to make organic fertilizer, consisted of 3 levels i.e (1) without inoculant, (2) EM4 and (3) Stardec. The second factor was incubation time, consisted of 4 levels i.e (1) 7 days, (2) 14 days, (3) 21 days and (4) 28 days. The control used organic fertilizer (Urea, SP36, KCl) with recommended dose. The result showed that neither organic fertilizer without inoculant nor with addition of EM4 and Stardec (with incubation time 7-28 days) affected significantly to the growth and yield of paddy, the used 3ton/hectare of organic fertilizer with or without inoculant did not affect significantly to the yield of paddy.

Keywords: Rice, Oryza sativa L., Inoculant, Organic Fertilizer

\section{PENDAHULUAN}

Padi (Oryza sativa L.) merupakan komoditas tanaman yang sangat penting karena menghasilkan bahan makanan pokok sebagian besar penduduk Indonesia yaitu beras. Setiap $100 \mathrm{~g}$ beras mengandung berbagai zat makanan yang diperlukan oleh tubuh antara lain karbohidrat 86,67 g; protein 8,67 g; lemak 2,45 $\mathrm{g}$; serat kasar 0,88 g dan abu 1,22 g. Selain itu beras juga mengandung beberapa unsur mineral antara lain kalsium dan magnesium (Anonim,
1994).

Perkembangan produksi padi di Indonesia sampai dengan tahun 1984 cukup menggembirakan sehingga dicapai swasembada beras, namun hal itu tidak dapat dipertahankan karena kemudian mengalami penurunan produksi antara lain disebabkan menurunnya rata-rata hasil dan berkurangnya lahan pertanian hingga 28,59 ribu hektar per tahun $(0,24$ $\%)$ akibat alih fungsi lahan pertanian menjadi 
pemukiman penduduk (perumahan), perkantoran, tempat usaha dan jalan (Anonim, 2007). Muchtadi (2007) mengemukakan bahwa selama periode 2001-2006 pertumbuhan produksi beras hanya $0,9 \%$, hal ini tidak dapat mengimbangi kenaikan konsumsi beras sebesar $2 \%$ sehingga pemerintah melakukan impor beras.

Pemerintah menargetkan peningkatan produksi padi dari 54.454 .937 ton pada tahun 2006 menjadi 55.127.430 ton pada tahun 2007, diharapkan produksi padi naik menjadi 1,23 \%. Usaha meningkatkan hasil padi dilakukan melalui intensifikasi, salah satu usahanya yaitu dengan menggunakan varietas unggul. Salah satu kekurangan varietas unggul adalah mempunyai respon positif terhadap pemberian pupuk kimia, artinya tanaman tersebut dapat memberikan hasil yang tinggi (maksimal) bila diberikan pupuk kimia (anorganik) dengan dosis tinggi (Murdjuki, 1990). Salikin (2003) mengemukakan bahwa pemberian pupuk kimia (anorganik) dengan dosis tinggi yang dilakukan terus menerus tanpa diimbangi pemberian pupuk organik dapat menimbulkan permasalahan diantaranya turunnya fungsi ekologis lahan yaitu kualitas daya dukung lahan pertanian yang kemungkinan besar akan mengancam keberlanjutan usaha pertanian dimasa mendatang.

Dari kenyataan tersebut, maka perlu dilakukan alternatif sistem budidaya yang mampu memberikan lingkungan tumbuh yang baik bagi tanaman danaman terhadap kelestarian daya dukung lahan. Alternatif yang ditawarkan untuk mengatasi intensifikasi dengan input luar (bahan kimia) tinggi yakni dengan sistem pertanian organik atau sistem usaha tani organik (organic farming system). Beberapa keuntungan sistem budidaya organik antara lain dapat mempertahankan kesuburan tanah, produksi tanaman stabil, daya dukung lahan lestari dan penghematan energi di masa datang.

Oleh karena itu, untuk mengembangkan produk pertanian (beras) organik dengan sistem pertanian yang berwawasan lingkungan dan berkelanjutan adalah dengan mengoptimalkan sumber daya lokal yang ada, yaitu mengembangkan padi varietas unggul lokal (varietas mentik wangi) dengan pemberian pupuk organik untuk meningkatkan pemberdayaan petani padi.Pupuk organik dapat dibuat sendiridari bahan organik yang tersedia di lingkungan petani antara lain limbah tanaman padi yaitu jerami. Sementara itu untuk mendapatkan pupuk organik yang berkualitas dalam waktu yang relatif cepat dapat ditambahkan inokulan, misalnya EM4 dan Stardec. Dalam pembuatan dan aplikasinya, untuk mendapatkan pengaruh yang terbaik dari pupuk organik tersebut perlu diketahui macam inoculum dan waktu inkubasi yang diperlukan dalam pembuatan pupuk organik tersebut sehingga berpengaruh positif terhadap pertumbuhan dan hasil padi.Penelitian ini bertujuan untuk mengetahui macam inokulan dan lama inkubasi dalam pembuatan pupuk organik yang dapat memberikan pengaruh paling baik pada pertumbuhan dan hasil padi.

\section{BAHANDAN METODE}

Penelitian dilaksanakan di tanah sawah di Desa Tamantirto, Kecamatan Kasihan, Bantul, DIY. Lokasi penelitian berada pada ketinggian tempat $100 \mathrm{~m}$ di atas permukaan laut dengan jenis tanah regosol. Pengamatan dan pengumpulan data dilakukan selama penelitian baik di lapangan maupun di Laboratorium Tanah, Laboratorium Penelitian (Produksi Tanaman) dan Laboratorium Statistik Fakultas Pertanian UMY. 
Bahan yang digunakan dalam penelitian ini adalah benih padi Varietas Mentik Wangi, kotoran ternak jerami, EM4, Stardec, pupuk Urea $(46 \% \mathrm{~N})$, pupuk SP-36 $\left(36 \% \mathrm{P}_{2} \mathrm{O}_{5}\right)$ dan $\mathrm{KCl}\left(60 \% \mathrm{~K}_{2} \mathrm{O}\right)$. Alat yang digunakan meliputi bajak, garu, cangkul, rollmeter, mistar, tugal, cetok, papan label, timbangan analitis, oven, leaf area meter, seed moister tester dan alat tulis.

Penelitian dilaksanakan menggunakan metode percobaan lapangan dengan rancangan perlakuan faktorial $3 \times 4+1$ perlakuan kontrol yang disusun dalam Rancangan Acak Kelompok Lengkap (Randomized Completely Block Design) dengan tiga blok sebagai ulangan. Faktor yang diujikan adalah macam inokulan yang ditambahkan dalam pembuatan pupuk organik, terdiri atas 3 aras yaitu tanpa inokulan, EM4 dan Stardec, sedangkan faktor lama inkubasi pupuk organik terdiri dari 4 aras yaitu 7 hari, 14 hari, 21 hari dan 28 hari ditambah 1 perlakuan kontrol dengan menggunakan pupuk anorganik (Urea, SP36 dan $\mathrm{KCl}$ ) sesuai dosis anjuran, sehingga ada 13 perlakuan.

Parameter yang diamati meliputi parameter pertumbuhan terdiri atas tinggi tanaman, jumlah daun dan jumlah anakan. Parameter hasil meliputi jumlah malai per rumpun, jumlah biji per malai, berat biji per tanaman, berat 1000 biji dan hasil biji per hektar.

Data hasil pengamatan dianalisis menggunakan sidik ragam (Analisys of Variance) dengan taraf kesalahan $5 \%$. Apabila ada perbedaan yang nyata antar perlakuan yang diujikan dilakukan uji jarak berganda Duncan (Duncan's New Multiple Range Test) pada taraf kesalahan 5\% (Gomez dan Gomez, 1994).

\section{HASIL DAN PEMBAHASAN}

\section{Parameter Pertumbuhan Tanaman}

Parameter pertumbuhan yang diamati meliputi tinggi tanaman, jumlah daun dan jumlah anakan. Hasil analisis varian pada tinggi tanaman menunjukkan bahwa tidak ada interaksi antara macam inokulan dengan lama inkubasi, tidak ada beda nyata antar macam inokulan dan antar lama inkubasi terhadap tinggi tanaman padi umur 9 minggu, namun demikian ada beda nyata antara pemberian pupuk organik dengan pemberian pupuk anorganik terhadap tinggi tanaman. Sementara hasil analisis varian jumlah daun dan jumlah anakan menunjukkan tidak ada interaksi antara macam inokulan dengan lama inkubasi, tidak ada beda nyata antar macam inokulan dan lama inkubasi terhadap jumlah daun dan jumlah anakan, serta tidak ada beda nyata antara pemberian pupuk organik dengan pupuk anorganik terhadap jurnlah daun dan jumlah anakan.

Angka rerata tinggi tanaman, jumlah daun dan jumlah anakan umur 9 minggu pada tabel 1 tidak dipengaruhi secara nyata baik dengan perlakuan macam inokulan maupun lama inkubasi. Hal ini menunjukkan bahwa penambahan inokulan EM4 dan Stardec dalam pembuatan pupuk organik belum berperan secara efektif dalam mempercepat dekomposisi bahan organik sehingga laju dekomposisi bahan organik pada perlakuan dengan penambahan inokulan dan tanpa penambahan inokulan sama. Dengan demikian unsur hara yang tersedia dan dapat diserap oleh tanaman untuk pertumbuhan atau pembentukan organ vegetatif juga sama (tidak berbeda nyata). Demikian pula perlakuan lama inkubasi dalam pembuatan pupuk organik 1-4 minggu dengan interval 7 hari (1minggu)tidak berpengaruh nyata terhadap pertumbuhan tanaman padi, yang berarti laju dekomposisi bahan organik dalam interval waktu 1-4 minggu relatif sama. 
Laju dekomposisi bahan organik yang sama akan berpengaruh terhadap sifat fisik, kimia dan biologi tanah yang sama sehingga pertumbuhan tanaman tidak berbeda nyata.

Pada tabel 1. ditunjukkan pula bahwa tinggi tanaman dengan perlakuan pemberian pupuk organik lebih rendah dibandingkan perlakuan dengan pemberian pupuk anorganik, hal ini terjadi karena jumlah unsur hara (nutrisi) hasil dekomposisi bahan organik lebih rendah atau sedikit dibandingkan dengan unsur hara yang terkandung dalam pupuk anorganik. Namun demikian hal tersebut tidak berpengaruh nyata terhadap jumlah daun dan jumlah anakan, hal ini ditunjukkan bahwa jumlah daun dan jumlah anakan pada perlakuan dengan pemberian pupuk organik dan dengan pupuk anorganik tidak berbeda nyata. Hal ini menunjukkan bahwa unsur hara (nutrisi) hasil dekomposi bahan organik dan iklim mikro dalam media tanam/ tanah yang diciptakan dengan pemberian pupuk organik mampu membentuk daun dan anakan dengan jumlah yang sama seperti halnya dengan pemberian pupuk anorganik.

\section{Parameter Hasil Tanaman}

Hasil analisis varian terhadap parameter hasil padi yang meliputi jumlah malai per rumpun, jumlah biji per malai, berat biji per rumpun, berat 1000 biji dan hasil biji per hektar menunjukkan bahwa tidak ada interaksi antara macam inokulan dengan lama inkubasi pada semua parameter hasil padi, tidak ada beda nyata antar perlakuan inokulan maupun lama inkubasi terhadap semua parameter hasil padi, dan tidak ada beda nyata pula antar perlakuan pupuk organik dengan pupuk anorganik terhadap semua parameter hasil padi.

Angka rerata jumlah malai per rumpun,
Tabel 1. Rerata Tinggi Tanaman, Jumlah Daun dan Jumlah Anakan Umur 9 Minggu

\begin{tabular}{llll}
\hline PERLAKUAN & TINGGI & JUMLAH & JUMLAH \\
& TANAMAN (CM) & DAUN & ANAKAN
\end{tabular}

Macam Inokulan

\begin{tabular}{llll} 
Tanpa inokulan & $84,787 a$ & $41,521 a$ & $8,625 a$ \\
EM4 & $89,754 a$ & $42,954 a$ & $8,417 a$ \\
Stardec & $87,683 a$ & $46,329 a$ & $9,279 a$ \\
Lama Inkubasi & & & \\
7 hari & $89,133 p$ & $42,250 p$ & $8,667 p$ \\
14 hari & $88,139 p$ & $45,467 p$ & $9,011 p$ \\
21 hari & $87,089 p$ & $44,611 p$ & $8,972 p$ \\
28 hari & $85,272 p$ & $42,078 p$ & $8,444 p$ \\
Interaksi & $(-)$ & $(-)$ & $(-)$ \\
Rerata & $87,518 x$ & $43,910 x$ & $8,767 x$ \\
Pupuk kimia & $88,417 \mathrm{y}$ & $45,050 \times$ & $9,450 x$ \\
\hline
\end{tabular}

Keterangan : Angka rerata yang diikuti huruf sama dalam kolom yang sama menunjukkan tidak berbeda nyata antar perlakuan berdasar sidik ragam dan kontras orthogonal pada tingkat kesalahan 5\%.(-) : tidak ada interaksi antar dua faktor yang diuji.

jumlah biji per malai, berat biji per rumpun, berat 1000 biji dan hasil biji padi. Pada Tabel 2 menunjukkan bahwa tidak ada pengaruh nyata dari perlakuan inokulan terhadap semua parameter hasil seperti halnya pengaruh terhadap pertumbuhan tanaman. Dengan tingkat pertumbuhan tanaman yang sama (tidak berbeda nyata) akan dihasilkan fotosintat untuk pembentukan organ generatif seperti bunga, malai dan biji dengan jumlah yang tidak berbeda nyata pula.

Pengaruh pemberian inokulan dalam pembuatan pupuk organik terhadap pertumbuhan dan hasil padi (Tabel 1 dan 2) walaupun tidak berbeda nyata, tampak adanya 
Tabel 2. Rerata jumlah malai per rumpun, jumlahbiji per malai, berat biji per rumpun,berat1000 biji dan hasil biji per hektar.

\begin{tabular}{llllll}
\hline PERLAKUAN & $\begin{array}{l}\text { JUMLAH MALAI } \\
\text { PER RUMPUN }\end{array}$ & $\begin{array}{l}\text { JUMLAH BIJI } \\
\text { PER MALAI }\end{array}$ & $\begin{array}{l}\text { BERAT BIJI } \\
\text { PER RUMPUN (G) }\end{array}$ & $\begin{array}{l}\text { BERAT } \\
1000 \text { BIJI (G) }\end{array}$ & $\begin{array}{l}\text { HASIL BIJI } \\
\text { (TON/HEKTAR) }\end{array}$ \\
\hline $\begin{array}{l}\text { MACAM INOKULAN } \\
\text { Tanpa Inokulan }\end{array}$ & $9,083 \mathrm{a}$ & $86,008 \mathrm{a}$ & $20,417 \mathrm{a}$ & $26,238 \mathrm{a}$ & $5,188 \mathrm{a}$ \\
$\begin{array}{l}\text { EM4 } \\
\text { Stardec }\end{array}$ & $9,550 \mathrm{a}$ & $84,553 \mathrm{a}$ & $21,633 \mathrm{a}$ & $26,586 \mathrm{a}$ & $5,373 \mathrm{a}$ \\
LAMA INKUBASI & $9,839 \mathrm{a}$ & $86,120 \mathrm{a}$ & $23,055 \mathrm{a}$ & $27,246 \mathrm{a}$ & $5,707 \mathrm{a}$ \\
7 hari & $9,233 \mathrm{p}$ & $83,009 \mathrm{p}$ & $20,642 \mathrm{p}$ & $26,661 \mathrm{p}$ & $5,092 \mathrm{p}$ \\
14 hari & $9,417 \mathrm{p}$ & $88,540 \mathrm{p}$ & $22,653 \mathrm{p}$ & $27,051 \mathrm{p}$ & $5,663 \mathrm{p}$ \\
21 hari & $9,722 \mathrm{p}$ & $86,550 \mathrm{p}$ & $21,921 \mathrm{p}$ & $23,630 \mathrm{p}$ & $5,416 \mathrm{p}$ \\
28 hari & $9,591 \mathrm{p}$ & $84,142 \mathrm{p}$ & $21,590 \mathrm{p}$ & $26,688 \mathrm{p}$ & $5,521 \mathrm{p}$ \\
Interaksi & $(-)$ & $(-)$ & $(-)$ & $(-)$ & $(-)$ \\
Rerata & $9,467 \mathrm{x}$ & $84,897 \mathrm{x}$ & $21,653 \mathrm{x}$ & $26,737 \mathrm{x}$ & $5,383 \mathrm{x}$ \\
Pupuk kimia & $9,750 \mathrm{x}$ & $91,273 \mathrm{x}$ & $23,263 \mathrm{x}$ & $26,307 \mathrm{x}$ & $5,817 \mathrm{x}$ \\
\hline
\end{tabular}

Keterangan : Angka rerata yang diikuti huruf sama dalam kolom yang sama menunjukkan tidak berbeda nyata antar perlakuan berdasar sidik ragam dan kontras orthogonal pada tingkat kesalahan 5\%.(-) : tidak ada interaksi antar dua faktor yang diuji.

kecenderungan bahwa dalam pembuatan pupuk organik dengan inokulasi EM4 maupun Stardec berpengaruh lebih baik terhadap pertumbuhan dan hasil padi dibandingkan pertumbuhan dan hasilpadi dengan aplikasi pupuk organik tanpa inokulan terutama pada parameter pertumbuhan tanaman padi (tinggi tanaman dan jumlah daun) dan parameter hasil padi (jumlah malai per rumpun, berat biji per rumpun, berat 1000 bijidan hasil biji per hektar) seperti terlihat pada gambar 1 dan 2 .

Seperti dinyatakan oleh Wididana dan Higa (1993) bahwa Efektif Mikroorganisme (EM) terdiri dari bakteri fotosintetik, Actinomycetes, ragi, jamur fermentasi dan bakteri penghasil laktat, yang tergabung dalam 10 genus dan 80 spesies. Bakteri fotosintetik tersebut memfiksasi nitrogen dari udara bebas dan mengkonsumsi senyawa-senyawa beracun untuk menjaga kesehatan dan produktivitas tanah. Ragi dan bakteri penghasil asam laktat bekerja sebagai peragi (fermenter) bahan organik. Hasil dari peragian bahan organik tersebut adalah berupa pelepasan asam amino dans akarida dalam bentuk senyawa organik terlarut yang dapat dimanfaatkan oleh tanaman untuk bermacammacam proses fisiologi seperti pembentukan sel, pembentukan organ vegetatif maupun organ generatif. Ditambahkan oleh Wididana dan Wibisana (1996) bahwa melalui peragian, mikroorganisme menghasilkan asam organik, hormon tanaman (auksin, giberelin, sitokinin), vitamin dan antibiotik. Senyawa-senyawa yang dihasilkan dari aktivitas mikroorganisme tersebut dapat bermanfaat untuk pertumbuhan tanaman, yaitu: 1) melarutkan unsur hara yang 
sukar terlarut misalnya batuan fosfat, 2) mereaksikan logam-logam berat agar terhambat penyerapannya oleh perakaran tanaman,3) menyediakan molekul organik sederhana seperti asam amino agar dapat diserap secara langsung oleh tanaman, 4) menjaga tanaman dari serangan hama dan penyakit, 5) merangsang pertumbuhan tanaman dan meningkatkan kuantitas dan kualitas hasil tanaman,6) memperbaiki sifat fisika, kimia dan biologi tanah. Pada saat seluruh pengaruh yang menguntungkan dari metabolisme mikroorganisme tersebut bergabung, menjadi optimal produktivitas tanah dan produksi tanaman tanpa menggunakan pupuk kimia dan pestisida. Hal ini ditunjukkan tidak adanya beda nyata hasil padi dari perlakuan pemberian pupuk organik dan hasil padi dengan pemberian pupuk anorganik (tabel 2). Demikian pula pengaruh baik dari inokulasi Stardec dalam pembuatan pupuk organik ditunjukkan pada parameter pertumbuhan tanaman padi (tabel 1) dan rerata hasil padi pada tabel 2. Bahkan terdapat kecenderungan pengaruh lebih baikdari pemberian inokulan Stardec dalam pembuatan pupuk organik dibandingkan EM4 terhadap pertumbuhan tanaman padi (jumlah daun dan jumlah anakan) serta semua parameter hasil padi, seperti tampak pada gambar 1 dangambar2. Stardec merupakan penemuan bioteknologi mikrobia probiotik anaerob penghasil enzim yang berfungsi untuk memecah karbohidrat, selulosa, hemiselulosa, lignin, protein serta lemak. Stardec yang ditambahkan pada bahan organik dalam pembuatan pupuk organik maka bakteri yang ada dalam Stardec akan membantu memecah struktur jaringan yang sulit terurai, dengan demikian lebih banyak nutrisi yang dapat diserap dan ditrasformasikan ke tanaman, sehingga

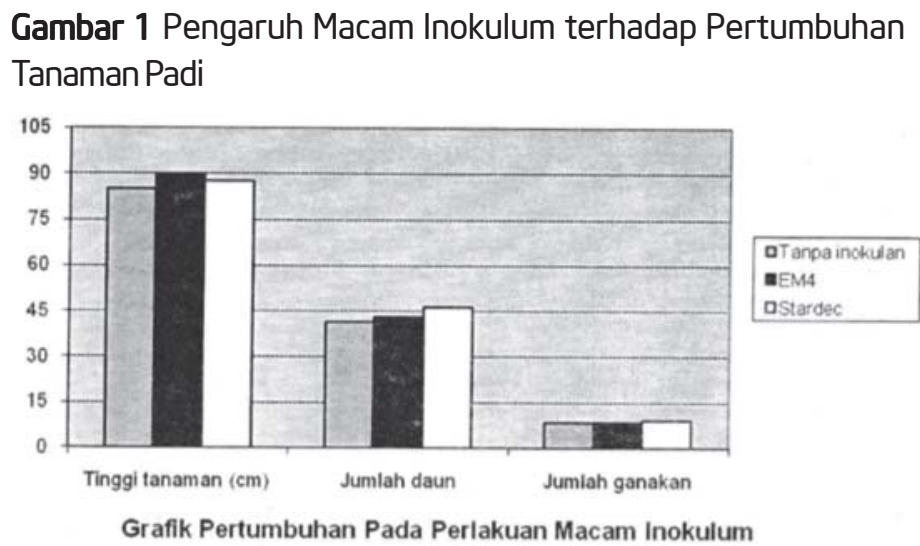

\section{Gambar 2 Pengaruh Lama Inkubasi terhadap Pertumbuhan Tanaman Padi}
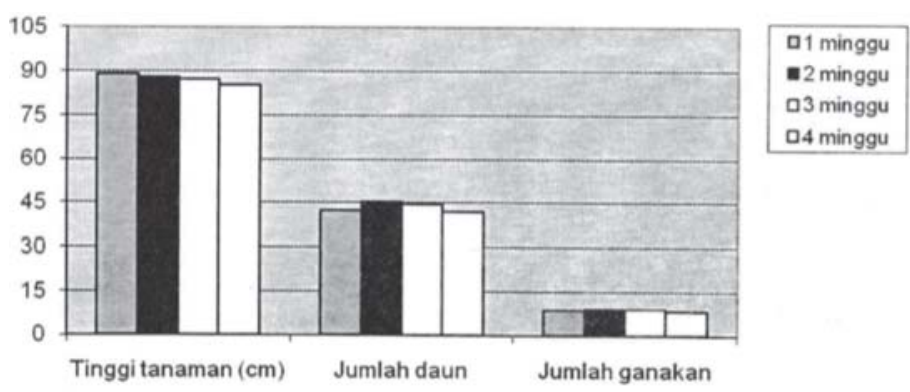

Grafik Pertumbuhan Pada Perlakuan Lama Inkubasi

produktivitas tanaman meningkat.

Pengaruh lama inkubasi dalam pembuatan pupuk organik terhadap pertumbuhan dan hasil padi dapat dilihat pada tabel 1 dan 2. Angka rerata semua parameter pertumbuhan dan hasil paditidak dipengaruhi secara nyata oleh perlakuan lama inkubasi. Hal ini menunjukkan bahwa tingkat dekomposisi bahan organik dalam masa inkubasi 1 - 4 minggu relatif sama sehingga jumlah nutrisi yang dapat tersedia dan dapat diserap oleh tanaman untuk pertumbuhan dan perkembangan tanaman juga sama. Namun demikian dari gambar 3 dan gambar 4 tampak ada kecenderungan bahwa lama inkubasi 2 minggu dalam pembuatan pupuk organik berpengaruh cenderung lebih baik terhadap pertumbuhan (jumlah daun dan jumlah anakan per rumpun) dan hasil padi 
(jumlah biji per malai, berat biji per rumpun, berat 1000 biji dan hasil biji) dibandingkan dengan lama inkubasi 1 minggu, 3 minggu dan 4 minggu. Hal ini dikarenakan pupuk organik dengan lama inkubasi 1 minggu belum terdekomposisi secara sempuma sehingga unsurunsur yang dapat diserap tanaman untuk pertumbuhan dan perkembangan tanaman masih terbatas atau sedikit, sedangkan lama inkubasi 2 minggu dalam pembuatan pupuk organik dekomposisi bahan organik sudah cukup baik dan mikroorganisme masih cukup banyak sehingga setelah diberikan pada media tanaman masih dapat berperan dalam meningkatkan kesuburan tanah, disamping unsur-unsur sudah cukup tersedia dari pupuk organik. Sementara itu lama inkubasi 3 dan 4 minggu dalam pembuatan pupuk organik, proses dekomposisi sudah sempuma namun mikroorganisme bermanfaat dari EM4 maupun Stardec kemungkinan sudah banyak yang tidak aktif atau mati.

Pengaruh pemberian pupuk organik terhadap hasil padi pada tabel 2 menunjukkan bahwa tingkat hasil padi dengan perlakuan pemberian pupuk organik 2 ton/ha tidak berbeda nyata dengan hasil padi dengan pemberian pupuk anorganik (Urea, SP36 dan $\mathrm{KCl}$ ) sesuai dosis anjuran. Hal ini menunjukkan adanya pengaruh baik dengan pemberian pupuk organik terhadap sifat fisik, kimia dan biologi tanah serta pertumbuhan dan hasil tanaman tanpa penambahan atau suplai unsur hara dengan pupuk kimia atau pupuk anorganik. Perbaikan sifat fisik tanah dari penambahan pupuk organik adalah meningkatnya daya sangga hara dan air tanah, agregasi tanah, permeabilitas dan aerasi tanah, luas zona perakaran, fluktuasi temperaturtanah serta mengurangi aliran permukaan (run-off). Hasil penelitian yang

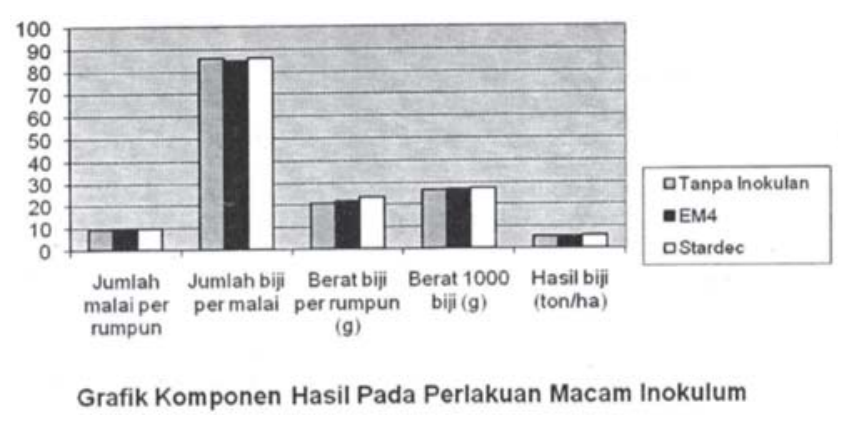

\section{Gambar3 Pengaruh Macam Inokulum Terhadap Hasil Tanaman Padi}

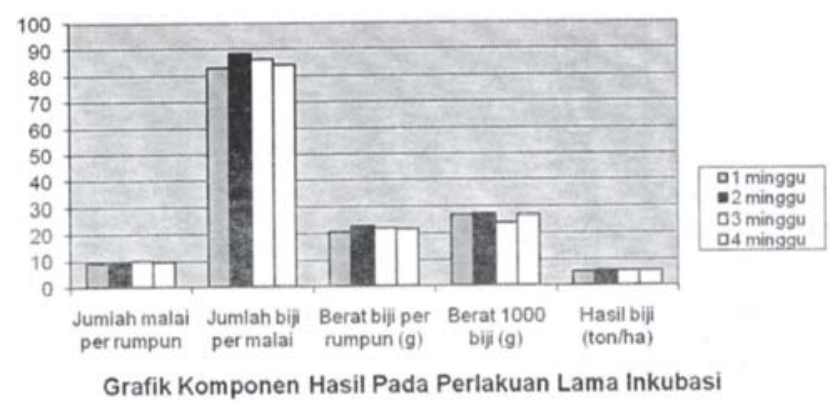

Gambar4 Pengaruh Lama Inkubasi Terhadap Hasil TanamanPadi

dilakukan Wididana (1995) menunjukkan bahwa pemberian pupuk organik dari sisa tanaman meningkatkan kadar C organik tanah sehingga stabilitas agregat meningkat dan erosi menurun. Fungsi pupuk organik dalam memperbaiki sifat kimia tanah diantaranya adalah menetralkan sifat racun dari $\mathrm{Al}$ dan $\mathrm{Fe}$ pada tanah masam, mengurangi fiksasi $\mathrm{P}$ oleh kation Fe dan $\mathrm{Al}$ dalam tanah masam serta kation Ca dan Mg dalam tanah alkali, menyangga hara tanaman, membantu menyediakan hara dan meningkatkan efisiensi pemupukan anorganik. Pelapukan bahan organik akan melepas unsur-unsur hara baik mikro maupun makro. Bahan organik mengandung hara makro N, P, K, Ca, Mg dan S serta hara mikro Si, Fe, Cu dan Zn (Karama et.al.,1996). Pengaruh pemberian pupuk organik terhadap sifat biologi tanah adalah 
meningkatkan aktivitas mikroorganisme sehingga kegiatan penguraian bahan organik juga meningkat, demikian unsur yang terdapat dalamtanah menjadi lebih tersedia bagi tanaman. Tersedianya bahan organik dalam tanah mempengaruhi populasi dan jenis mikroorganisme tanah (Wididana, 1995). Bahan organik merupakan sumber utama energi bagi aktivitas mikroorganisme tanah. Penambahan bahan organik dengan rasio $\mathrm{C} / \mathrm{N}$ yang tinggi mendorong pembiakan mikroorganisme dan mengikat beberapa unsur hara tanaman sehingga menyebabkan kekurangan sementara. Setelah rasio $\mathrm{C} / \mathrm{N}$ turun maka sebagian mikroorganisme mati dan melepaskan kembali unsur hara ke dalam tanah (Karama et.al., 996). Pada tanah yang bahan organiknya rendah akan mempunyai populasi mikroorganisme dan kesuburan tanah yang rendah pula. Pemberian pupuk organik ke dalam tanah mempunyai arti yang sangat penting terhadap kesuburan tanah, karena hampir sebagian besar transformasi bahan organik dilakukan oleh mikroorganisme. Jadi pemberian bahan organik atau pupuk organik dapat memperbaiki atau meningkatkan kesuburan tanah,membuat tanah menjadi kondusif untuk pertumbuhan akar tanaman sehingga penyerapan air dan unsur hara lebih baik (meningkat), dengan demikian dapat meningkatkan pertumbuhan danhasil tanaman.

Bila dilihat hasil padi dari perlakuan pupuk organik dan pupuk anorganik, walaupun tidak ada beda nyata namun ada kecenderungan perlakuan dengan pupuk anorganik memberikan hasil lebih tinggi terutama pada parameter jumlah malai per rumpun, jumlah biji per malai, berat biji per rumpun dan hasil biji per hektar, hal ini dikarenakan kandungan unsur hara yang tersedia dan dapat diserap serta dimanfaatkan untuk pertumbuhan dan perkembangan tanaman padi dalam pupuk anorganik lebih banyak dari pada pupuk organik.

\section{SIMPULAN}

Pupuk organik tanpa inokulan, dengan penambahan inokulan EM4 maupun Stardec dalam pembuatan pupuk organik (pupuk kandang ayam) dengan lama inkubasi 1-4 minggu tidak berpengaruh nyata terhadap pertumbuhan dan hasil padi Varietas Mentik Wangi. Penggunaan pupuk organik (pupuk kandang ayam) 3 ton/ha tanpa inokulan, dengan menggunakan inokulan EM4 maupun Stardec memberikan hasil padi yang tidak berbeda nyata dengan hasil padi menggunakan pupuk anorganik.

\section{DAFTAR PUSTAKA}

Anonim. 1994. Budidaya Tanaman Padi.Kanisius. Yogyakarta. Biro Pusat Statistik Indonesia.2007.Tanaman pangan padi.www.bps.go.id. Yogyakarta.

Gomez, K.A. and A.A. Gomez. 1994.StatisticalProceduresfor AgriculcuralResearch

An International Rice Research Institute Book. A. Wiley Interscience Publication. John Willey \&Sons. New York.

Karama,A.S., J.S. Adiningsihdan D.Nursyamsi. 1996. Peningkatan Produksi Tanaman Pangan Melalui Pertanian Organik. Makalah Seminar Nasional Penerapan Teknologi Pertanian Organik. Tasikmalaya, 15 Mei1996. Univ. Siliwangi, Tasikmalaya.

Mardjuki, A. 1990. Pertanian dan Masalahnya.Pengantar IImu Pertanian. Andi Offset Yogyakarta.

Muchtadi, R.T. 2007. Program Peningkatan Produksi Beras 2 juta ton per tahun www.Tempo Interaktif. Yogyakarta.

Salikin, K.A. 2003.Sistem PertanianBerkelanjutan. Kanisius. Yogyakarta.

Wididana. 1995. Pemanfaatan Limbah Organik Untuk Pupuk. Tumbuh IV (40): 29.

Wididana dan T.Higa. 1993. Seri Pertanian Akrab Lingkungan Pemanfaatan Bercocok Tanam Padi dengan Teknologi EM4. PT Songgo Langit Persada.

Wididana dan A.H. Wibisana. 1996.Pertanian Akrab Lingkungan Kyusai dengan Teknologi EM. Makalah Seminar Nasional Penerapan Teknologi Pertanian Organik. Tasikmalaya, 15 Mei1996. Univ. Siliwangi, Tasikmalaya. 